The Business Rhetoric Research Group

\title{
Introduction to Thematic Section on Business Rhetoric
}

The art of rhetoric, rhetorike techne, emerges as a discipline in Sicily in the 5th century, in the early days of the classical age. It arises in the wake of the many legal processes where claims were made for return of propriety in cities like Agrigento and Siracusa after the fall of the tyrans. Corax and Tisias, and after them the sophists Gorgias and Isocrates, were among the very first to write handbooks on how to design and put together persuasive speeches. At little more than a hundred years later, Aristotle writes his famous treatise Rhetoric, and after this ,the art of persuasion" and its conceptual system has become an integral part of western culture. Throughout history, rhetoric has occasionally assumed a humble position, but it has always been rescued from total oblivion and it has recently become the subject of new theoretical and practical debates.

The emergence of rhetoric was closely tied to a specific political system and a specific type of social practice, ie the antique city-state or polis and its legal processes. Its purpose was, accordingly, first of all functional: to prompt or to dissuade, to accuse or to defend, to praise or to blame. However, during the following centuries, and especially after the Renaissance, this rhetorical pragmatic falls into decay and turns into an aesthetic. The five partes, inventio, dispositio, elocutio, memoria and actio, are, so to say, reduced to pure elocutio. In the 19th century, rhetoric almost disappeared, replaced as it was by stylistics.

Nevertheless, in the 20th century, rhetoric has been witnessing a farreaching revival bringing with it an important extension of its traditional fields of activity: the political speech, the legal speech or the epideitic speech. Within North American neo-rhetoric, the critique of neoaristotelian rhetoric has given rise to a remarkable series of new types of rhetorical criticisms, among others pentadic criticism and generic criticism. At the same time, the conceptual system of rhetoric has been 
brought into play within a wide range of new fields: the rhetoric of literary works, the rhetoric of science, the rhetoric of images, etc.

Why not then also apply the rhetorical approach to the many-coloured multiplicity of texts within the world of modern business? From the language use of managers to advertising and public relations, from crisis communication to environmental communication, from company brochures to employment pages, and from economical text books to ,how to use" manuals within business administration.

In 1999 a research group within the upcoming discipline of business rhetoric was created at the Aarhus School of Business. Departing from a true interdisciplinary perspective, it counts members from both the Faculty of Business Administration and the Faculty of Modern Languages. The overall goal of the research group is to study the rhetoric within a range of important business areas, including both rhetorical topics in the traditional sense (from topoi to the use of metaphors and argumentation) and the role played by or assigned to communication within these areas. The two areas investigated so far by the research group are management and marketing. To these two areas belong both a scientific discourse (monographs, articles, text books, etc.) and communication within specific fields of practice (like marketing communication or management communication).

The thematic section of this issue of Hermes consists of three articles presenting some of the findings of the Business Rhetoric Research Group and showing in which directions business rhetoric can and will move in the future in terms of methodology and empirical objects. Hanne Nørreklit and Camilla Kølsen de Wit's article analyses how a successful manager communicates ideas and plans to the employees using a rhetoric based on his social competence and his ability to communicate. In their contribution, Poul Houmann Andersen and Anne Ellerup Nielsen apply a semiotic mapping approach in order to investigate the brand values and the marketing communication strategies used by Danish banks in their relationship marketing. Finally, Finn Frandsen and Winni Johansen analyse how Danish hotels try to get round some of the paradoxes of green marketing by means of environmental rhetoric. 